\title{
Written feedback in an English Language writing class
}

\author{
Wan Hurani Osman \\ Centre for the Promotional Knowledge and Language Learning \\ Universiti Malaysia Sabah, Kota Kinabalu, Sabah, Malaysia \\ Email:wanosman@ums.edu.my
}

DOI: https://doi.org/10.37134/ajelp.vol7.1.1.2019

Cite this article (APA): Osman, W. H. (2019). Written feedback in an English Language writing class. AJELP: Asian Journal of English Language and Pedagogy, 7(1), 1-14. https://doi.org/10.37134/ajelp.vol7.1.1.2019

\begin{abstract}
The Malaysian English syllabi for primary schools, secondary schools, and higher learning institutions focus mainly on the four skills, i.e. listening, speaking, reading, and writing. Among the four skills, writing is the most difficult skill to master, and it becomes harder when using a second language. Because of this, when students write in a second language, it is very important that the feedback they receive are useful and motivating. There are many views on what academics give as feedback and how it is given which will help to motivate and improve the students' writing. This paper attempts to identify the common practices and styles of giving feedback by academics at a public university in Malaysia. The respondents for this research are students and academics, who were learning and teaching an academic writing module in the university. The students were given a questionnaire which was adapted from Montgomery \& Baker (2007) and Lee (2003) and the academics were interviewed in order to obtain in-dept information regarding the matter being investigated. This research also aims to obtain the students' perceptions and suggestions on what they consider as good, clear, and motivating feedback.
\end{abstract}

Keywords feedback, second language learners, academic writing, student perception, feedback practices

\section{INTRODUCTION}

Naginder Kaur (2006), Jalaludin, Norsimah and Kesumawati (2008), and Che Musa, Koo and Azman (2013) are a few Malaysian researchers who have expressed their concerns over the low literacy attainment in the English language among Malaysian learners. They have conducted research to discover reasons that led to Malaysian students' low English literacy despite having gone through 11 years of learning English in school. Among the four skills, writing is found to be the most difficult skill to acquire (Fareed, Ashraf \& Bilal, 2016; Nunan, 1989).

According to Myles (2002), to be a good writer is not a '... naturally acquired skill; it is usually learned or culturally transmitted as a set of practices in formal 
instructional settings or other environments. Writing skills must be practiced and learned through experience' (p. 1). Writing is a skill that requires a person to compose, which is to either '.. tell or retell pieces of information in the form of narratives or description, or to transform information into new texts, as in expository or argumentative writing' (Myles, 2002, p. 3).

It is acknowledged that it is not an easy task to be a good writer. This is even more true when one needs to write in a second language. Thus, academics need to play an important role in improving students' writing skill. One of the factors that influences a student's interest and motivation to write in a second language is the feedback that one receives, either spoken or written. Mirzaii and Aliabadi (2013) highlighted that motivation to write involves 'a transformation in two closely connected areas, namely, writing instruction and written corrective feedback.' (p. 192). Hence, teaching writing is always related to giving and receiving feedback. It is a part of the process of writing where a good piece of writing requires editing and revising.

Giving feedback on students' writing is an important skill that is seldom taught. Through feedback, academics can assist students to compare their own performance with the ideal essay model, and to diagnose their own strengths and weaknesses. Feedback that is given directly or indirectly can improve students' writing. But there will always be the question of what type of feedback that will give the best impact to improve students' writings, and not only as a short-term measure or a temporary solution to this occurrence. Roger (2001) discovered that some feedback from teachers are unhelpful, because it tends to be too general or unclear, subjective, and only focus on some aspects of performance that do not help the students to change. Thus, how can a student improve one's writing?

Many researchers have looked at the use of feedback on students' writing. Among them are Montgomery and Baker (2007) who stated:

Through L2 writing teachers are aware of students' perceptions of written feedback and most try to give helpful feedback to their students, teachers may not be fully aware of how much feedback they give on local (i.e. spelling, grammar and punctuation) and global (i.e. ideas, content and organisation) issues or whether the type of feedback they feel they should adhere to their beliefs about written feedback (p. 83).

They also found that there is an argument on what the focus of a feedback should be, for example, local versus global. It is interesting to observe how some teachers focus on global issues in students' first drafts, but later focus on local issues in the following drafts (Montgomery \& Baker, 2007). This view is also mirrored by Peterson and McClay (2010):

Assessing writing and providing feedback to students are social practices; these practices are influenced by teachers' views on what constitutes a good writing and a good teaching practice within both their local contexts and the broader contexts of education and society (Barton, 2001; Barton, Hamilton, \& Ivanic, 2000). We are interested in the ways in which teachers take up the values, perceptions, and the socio-cultural understandings of effective writing assessment and good writing in their day-to-day interactions with students (p.89). 
Another researcher, Lee (2003) mentioned:

...literature on error correction has highlighted several issues that are particularly pertinent to teachers while they are correcting errors. Teachers have to decide whether: (1) to correct or not to correct errors; (2) to identify or not to identify error types; and (3) to locate errors directly or indirectly. First of all, should teachers correct errors for students - i.e. should teachers give direct error feedback? There is research evidence to indicate that indirect feedback (i.e. indicating errors without correcting them) brings more benefit to students' longterm writing development than direct feedback (Ferris, 2002; Frantzen, 1995; Lalande, 1982). Ferris (2002) suggests that indirect feedback is generally more appropriate and effective than direct feedback. The danger of direct feedback is that teachers may misinterpret students' meaning and put words into their mouths ( $p$. 217).

Abdullah and Sidek (2012) revealed the inconsistencies between teachers' and students' views regarding feedback on writing, for instance, the alignment between writing tasks and focus of feedback. Abdullah and Sidek (2012) found that teachers do not fully comprehend the concept of the Process Writing Approach. There was a mismatch between their declared approach and implementation. This study also provided teachers with some insights into effective ways of assisting students in learning to analyse their weaknesses and develop their writing skills. A high proportion of students declared that they did not seem to benefit much from the feedback provided by their teachers as students focused on structure more than on other aspects of writing, such as content, organisation, and style.

In view of what has been mentioned by Lee (2003) and the other researchers, there is a need to investigate the practices of academics who are teaching writing in a public university in Malaysia. Thus, this study aims to answer two main research questions:

1) What are the errors that are frequently highlighted by the lecturers in a writing module class?

2) What are the common practices and styles of giving feedback by the lecturers in a Malaysian public university?

This paper is significant to both academics and students in general. It is hoped that this study can contribute to improving academics' quality in giving feedback. As for students, this study aims to assist them to improve and develop their own writing based on the feedback from the lecturers, and thus become better English language writers.

\section{METHODOLOGY}

This study used a survey design to answer the two main research questions. As described by Creswell (2012), a survey is conducted to describe opinions, behaviors or attitudes towards something. A survey design is a quantitative research that uses 
'questionnaires (e.g., mailed questionnaires) or interviews (e.g., one-on-one interviews) and statistically analyse the data...' (Creswell, 2012, p. 376).

This present study was a cross-sectional study, where the study was conducted on a group of academics and students who had been giving and receiving feedback on their written work at one chosen public university. Both group of respondents were teaching and learning an academic writing module being offered in the university. These two groups were used because there was a need to ensure that what the students view as feedback are in-line with what was intended by the academics giving the feedback. This helped justify and triangulate the data obtained.

This research involved two groups of respondents; six academics who taught the academic writing module, and 40 students who registered for the module. The academics were chosen randomly, based on their availability to be interviewed. However, all the six academics have taught the module for more than one year and have been in the teaching profession for a minimum of three years. The students were chosen from a few sections that were taught by the academics who participated in this research. Prior to distributing the questionnaire, students who were willing to participate were identified. From roughly 120 students, only 40 students were willing to participate.

For the particular semester, students who took the academic writing course had scored Bands 1, 2, and 3 in the Malaysian University English Test (MUET). MUET is a test that was introduced by the Ministry of Education to fulfil two purposes: to improve the teaching of English as an important second language; and to enhance the English language proficiency of Sixth Formers and other pre-university students. The first implementation was in 2000. According to MUET (2004), 'the syllabus aims to equip students with the appropriate level of proficiency in English to enable them to perform effectively in their academic pursuits at tertiary levels'. In this public university, students must have a minimum Band 1 in MUET in order to enter an undergraduate program. For students with MUET Bands 1, 2, and 3, they must take four levels of English in the university. Prior to Academic Reading and Writing module, students have sat for three other English Language courses which focused on grammar, oral and listening skills. They have to take and pass these three courses before they can take an academic writing course, which is the last English Language course that the students have to take. As for students with MUET Bands 4, 5, and 6, they only have to take one level of English language course offered.

\section{Instrumentations}

The instruments used were a set of questionnaire and interview. The questionnaire was adapted from Montgomery and Baker (2007) and Lee (2003). The two questionnaires were adapted in this present study, because the objectives of Montgomery and Baker's (2007) and Lee's (2003) researches are similar to the present study. The questionnaire was divided into three main sections, i.e. Section A (Demography), Section B (Do you usually receive these aspects as feedback?), and Section C (Opinions).

Students were given the questionnaires at the end of the semester. However, before the questionnaire was distributed, it was validated by two English language academics who are experts in writing, and they have taught writing for more than five years.

As for the second group of respondents who were the academics, they were interviewed to obtain their views and practices in giving feedback. The six academics were randomly chosen out of ten full-time academics who were teaching the module 
during that particular semester. In general, there were three main interview questions, which were:

Question 1: What is the main purpose of providing feedback on students writing?

Question 2: How many times do lecturers usually allow students to write their drafts and why?

Question 3: In relation to other writing genre classes, how is the feedback similar or different from those given in the academic writing genre especially in this specific writing course?

\section{RESULTS}

The results section is divided into two parts. The first is the result from the questionnaires which only involved the group of 40 students and the second part of this results section will reveal results obtained from the interview session involving the 6 academics.

\section{Questionnaires}

There were 40 students who participated in this research. However, seven questionnaires were void because six respondents ticked all the sections, and one respondent answered only Section A.

Table 1 describes the demography of the respondents. It shows that the respondents of the questionnaires were of mixed races and ages, where 61 percent $(20 / 22)$ were female students. The majority of the respondents were Bumiputras (82\%) with 12 Malay students and 15 others. The others were from Sabah ethnicity which are Kadazan, Dusun and Bajau. The majority of the respondents were from the MUET Band 2 group (16 students), i.e. their English is at the intermediate level, and only 3 students were at the low proficiency level. The age of the respondents varied from 18 to 25 years old. This age gap could be due to a delay in the university entrance or they were repeaters of the module.

Table 1: Respondents' demographic information.

\begin{tabular}{|l|c|c|}
\hline & No of Respondents & Percentage \\
\hline Malay & 12 & $36.3 \%$ \\
\hline Chinese & 6 & $18.2 \%$ \\
\hline Indian & 0 & 0 \\
\hline Others & 15 & $45.5 \%$ \\
\hline Female & 20 & $60.6 \%$ \\
\hline Male & 13 & $39.4 \%$ \\
\hline MUET Band 1 & 3 & $9.1 \%$ \\
\hline MUET Band 2 & 16 & $48.5 \%$ \\
\hline MUET Band 3 & 14 & $42.4 \%$ \\
\hline Age $18-20$ & 1 & $3 \%$ \\
\hline Age $21-22$ & 24 & $72.7 \%$ \\
\hline
\end{tabular}




\begin{tabular}{|l|l|l|}
\hline Age $23-25$ & 8 & $24.3 \%$ \\
\hline
\end{tabular}

The second section of the questionnaire which was 'Section B: Do you usually receive these aspects as feedback?' This section asked the respondents about the common feedback items they received when they submit their written work. This section is further sub-divided into nine questions, as shown below:

\section{1) Prior grammar instruction given in class}

For this question, the students were asked whether they were given any grammar explanation/instruction before writing. Table 2 shows the students' responses to the frequency of grammar instruction prior to their writing. For the first draft, 58 percent $(19 / 33)$ of the students reported that they received a considerable amount of explanation prior to writing. However, 76 percent $(25 / 33)$ admitted that a lot of grammar explanation was given before submitting their second draft.

As shown in Table 2, it can be concluded that in a writing class, the academics provided more grammar guidance once they had identified that the students are weak or need help in grammar. However, the students mentioned that academics did not focus too much on teaching grammar items after the second draft. This is evident when only 10 students $(30 \%)$ responded 'a lot' of grammar instruction were given in class before submitting their final draft.

Table 2: Prior grammar instruction given in class.

\begin{tabular}{|l|c|c|c|}
\hline $\begin{array}{c}\text { Prior grammar instruction } \\
\text { given in class. }\end{array}$ & First Draft & Second Draft & Final Draft \\
\hline A lot & $19(57.6 \%)$ & $25(75.8 \%)$ & $10(30.3 \%)$ \\
\hline Sometimes & $11(33.3 \%)$ & $8(24.2 \%)$ & $8(24.2 \%)$ \\
\hline Very little & $3(9.1 \%)$ & 0 & $13(39.4 \%)$ \\
\hline Never & 0 & 0 & $2(6.1 \%)$ \\
\hline
\end{tabular}

\section{2) Types of grammar problems identified by tutor/lecturer}

Table 3 shows that in the first draft, the academics gave the most emphasis on verb and sentence structure ( 94 percent, (31/33), followed by articles ( 85 percent), and word choice ( 82 percent). However, when it came to the final product, sentence structure was given the least emphasis with only 27 percent (9/33) respondents said that it was identified by their academics. The data also revealed that the academics' feedback decreased during the third round of the feedback process.

Table 3: Types of grammar problems identified by tutor/lecturer.

\begin{tabular}{|l|c|c|c|}
\hline $\begin{array}{l}\text { Types of grammar problems } \\
\text { identified by tutor/lecturer. }\end{array}$ & First Draft & Second Draft & Final Draft \\
\hline Verbs & $31(93.9 \%)$ & $27(81.8 \%)$ & $12(36.4 \%)$ \\
\hline Nouns & $26(78.8 \%)$ & $26(78.8 \%)$ & $12(36.4 \%)$ \\
\hline Articles & $28(84.8 \%)$ & $25(75.8 \%)$ & $10(33.3 \%)$ \\
\hline Wrong word & $27(81.8 \%)$ & $26(78.8 \%)$ & $12(36.4 \%)$ \\
\hline Tenses & $24(72.7 \%)$ & $25(75.8 \%)$ & $9(27.3 \%)$ \\
\hline
\end{tabular}


Sentence structure

$31(93.9 \%)$

$28(84.8 \%)$

$9(27.3 \%)$

3) How concerned was your tutor/lecturer about grammatical accuracy?

Table 4 shows that concerns about grammar accuracy was high, especially during the first and second round of feedback. In the first draft, 85 percent $(28 / 33)$ of the students responded, 'very much' and 'much' and this proved that grammar accuracy is important to academics teaching writing. The concerned on grammar accuracy increased in the second draft with 89 percent $(29 / 33)$ of the respondents chose 'very much' and 'much'. This finding helps to verify the response to Question 1 (grammar instruction given in class).

Table 4: How much concern does your tutor/lecturer have about grammatical accuracy?

\begin{tabular}{|l|c|c|c|}
\hline $\begin{array}{c}\text { How much concern does your } \\
\text { tutor/lecturer have about } \\
\text { grammatical accuracy? }\end{array}$ & First Draft & Second Draft & Final Draft \\
\hline Very much & $18(54.5 \%)$ & $17(51.5 \%)$ & $10(30.3 \%)$ \\
\hline Much & $10(30.3 \%)$ & $12(36.4 \%)$ & $2(6.1 \%)$ \\
\hline Average & $5(15.2 \%)$ & $4(12.1 \%)$ & $2(6.1 \%)$ \\
\hline Little & 0 & 0 & $12(36.4 \%)$ \\
\hline Very little & 0 & 0 & $7(21.1 \%)$ \\
\hline
\end{tabular}

\section{4) How concerned was your tutor/lecturer about organisation?}

Since this was an academic writing class that focused on one specific genre, which was the academic genre, organisation was important. Table 5 shows that 100 percent $(33 / 33)$ of the respondents agreed that organisation was given much emphasis. None of the respondent responded little or very little. Organisation in an academic text is important because it helps reading and understanding the content of the writing.

Table 5: How much concern does your tutor/lecturer have about organisation?

\begin{tabular}{|l|c|c|c|}
\hline $\begin{array}{c}\text { How much concern does your } \\
\text { tutor/lecturer have about } \\
\text { organisation? }\end{array}$ & First Draft & Second Draft & Final Draft \\
\hline Very much & $16(48.5 \%)$ & $15(45.5 \%)$ & $28(84.9 \%)$ \\
\hline Much & $11(33.3 \%)$ & $14(42.4 \%)$ & $1(3 \%)$ \\
\hline Average & $6(18.2 \%)$ & $4(12.1 \%)$ & $4(12.1 \%)$ \\
\hline Little & 0 & 0 & 0 \\
\hline Very little & 0 & 0 & 0 \\
\hline
\end{tabular}

5) How concerned was your lecturer about content/ideas appropriateness?

Table 6 shows that 85 percent of the students (20 "very much" and 8 "much") reported that content was much emphasised in the feedback given by the academics. When it came to the second draft, the result increased to 88 percent of the students $(29 / 33)$ who said that the academics gave more feedback on this area. In an academic text, the main ideas and supporting details are important and these contents and ideas 
differentiate between an academic text and non-academic text. However, the result shows a decline on the emphasis on content and ideas in the final draft. This may be because the lecturers have stressed on it in the first two drafts.

Table 6: How much concern does your lecturer have about content/ideas appropriateness?

\begin{tabular}{|l|c|c|c|}
\hline $\begin{array}{c}\text { How much concern does your } \\
\text { lecturer have about } \\
\text { content/ideas } \\
\text { appropriateness? }\end{array}$ & First Draft & Second Draft & Final Draft \\
\hline Very much & $20(60.6 \%)$ & $18(54.6 \%)$ & $17(51.5 \%)$ \\
\hline Much & $8(24.2 \%)$ & $11(33.3 \%)$ & $7(21.2 \%)$ \\
\hline Average & $5(15.2 \%)$ & $4(12.1 \%)$ & $7(21.2 \%)$ \\
\hline Little & 0 & 0 & $2(6.1 \%)$ \\
\hline Very little & 0 & 0 & 0 \\
\hline
\end{tabular}

6) How concerned was your tutor/lecturer about vocabulary accuracy?

Table 7 shows that 100 percent of the students stated that aspect of vocabulary were highlighted in the feedback that they received in all the feedback stages; the first, second and final drafts. Without the appropriate word, the content and ideas cannot be conveyed clearly. Thus, the concern on vocabulary.

Table 7: How much concern does your tutor/lecturer have about vocabulary accuracy?

\begin{tabular}{|l|c|c|c|}
\hline $\begin{array}{c}\text { How much concern does your } \\
\text { tutor/lecturer have about } \\
\text { vocabulary accuracy? }\end{array}$ & First Draft & Second Draft & Final Draft \\
\hline Very much & $13(39.4 \%)$ & $21(63.6 \%)$ & $12(36.4 \%)$ \\
\hline Much & $17(51.5 \%)$ & $9(27.3 \%)$ & $10(30.3 \%)$ \\
\hline Average & $3(9.1 \%)$ & $3(9.1 \%)$ & $11(33.3 \%)$ \\
\hline Little & 0 & 0 & 0 \\
\hline Very little & 0 & 0 & 0 \\
\hline
\end{tabular}

7) How concerned was your lecturer about mechanics (punctuation, spelling, format) accuracy?

Table 8 shows that throughout the three drafts, academics highlighted the mechanics of writing. However, this focus was reduced, as the number of students' drafts increased. 57.5 percent (19/33 students) said a lot of the mechanics were highlighted in the first draft, followed by 54.5 percent (18/33 students) in the second and in the final draft only 42.4 percent (14/33 students) said it was a concern to their academics.

Table 8: How much concern does your lecturer have about Mechanics accuracy?

\begin{tabular}{|l|c|c|c|}
\hline $\begin{array}{c}\text { How much concern does } \\
\text { your lecturer have about } \\
\text { Mechanics accuracy? }\end{array}$ & First Draft & Second Draft & Final Draft \\
\hline Very much & $19(57.5 \%)$ & $18(54.5 \%)$ & $14(42.4 \%)$ \\
\hline Much & $8(24.3 \%)$ & $8(24.3 \%)$ & $4(12.1 \%)$ \\
\hline
\end{tabular}




\begin{tabular}{|l|c|c|c|}
\hline Average & $6(18.2 \%)$ & $6(18.2 \%)$ & $4(12.1 \%)$ \\
\hline Little & 0 & $1(3 \%)$ & $5(15.2 \%)$ \\
\hline Very little & 0 & 0 & $6(18.2 \%)$ \\
\hline
\end{tabular}

8) What is your feedback preference?

Table 9 shows that 36 percent of the students (12/33) preferred to have all errors corrected by the lecturers when the latter gave feedback, and this was followed by 'correct most serious errors' (30 percent) and 'circle and label error types' (27 percent). However, the preference changed drastically for the final draft where 21 percent (7/33 students) choose 'don't correct'. This may be because they do not need to correct their mistakes after the final draft.

Table 9: What is your feedback preference?

\begin{tabular}{|l|c|c|c|}
\hline \multicolumn{1}{|c|}{$\begin{array}{c}\text { What is your feedback } \\
\text { preference? }\end{array}$} & First Draft & Second Draft & Final Draft \\
\hline Don't correct & 0 & 0 & $7(21.3 \%)$ \\
\hline Correct most serious & $10(30.3 \%)$ & $14(42.5 \%)$ & $1(3 \%)$ \\
\hline Circle errors & $2(6 \%)$ & $1(3 \%)$ & $6(18.1 \%)$ \\
\hline Circle and label error types & $9(27.3 \%)$ & $6(18.1 \%)$ & $9(27.3 \%)$ \\
\hline Correct all errors & $12(36.4 \%)$ & $12(36.4 \%)$ & $10(30.3 \%)$ \\
\hline
\end{tabular}

9) How much do you enjoy writing in English?

Table 10 shows that the students enjoyed writing in English with 14/33 students enjoyed "very much", and 10/33 enjoyed "much" when writing their first draft. However, the numbers declined in their enjoyment, as the writing process developed into the final draft. The number of students enjoying writing "very much" dropped from 14 students in the first draft to 10 students in the final draft. 4/33 students $(12.2 \%)$ said they enjoyed 'very little' writing in English compared to only 1/33 (3\%) when writing the first draft and $0 \%$ when writing the second draft.

Table 10: How much do you enjoy writing in the English Language?

\begin{tabular}{|l|c|c|c|}
\hline $\begin{array}{c}\text { How much do you enjoy } \\
\text { writing in the English } \\
\text { Language? }\end{array}$ & First Draft & Second Draft & Final Draft \\
\hline Very much & $14(42.4 \%)$ & $13(39.4 \%)$ & $10(30.3 \%)$ \\
\hline Much & $10(30.3 \%)$ & $8(24.2 \%)$ & $6(18.2 \%)$ \\
\hline Average & $6(18.2 \%)$ & $8(24.2 \%)$ & $6(18.2 \%)$ \\
\hline Little & $2(6.1 \%)$ & $4(12.2 \%)$ & $7(21.1 \%)$ \\
\hline Very little & $1(3 \%)$ & 0 & $4(12.2 \%)$ \\
\hline
\end{tabular}

\section{Opinions}

Section $\mathrm{C}$ consisted of 1 open-ended question and 2 multiple-choice questions. The open-ended question which was the first question for Section $\mathrm{C}$ aims to identity what 
the students know about feedback and do they know the main purpose of academics giving feedback on their writings?

From the data in Table 11, it can be concluded that students understood the reason for receiving feedback. Receiving and understanding the feedbacks will assist in identifying whether the students' work or product is appropriate and correct (Hattie \& Timperley, 2007)).

There were four students who gave three reasons; correcting mistakes, improving writing and improving grammar (Respondent 3, 14, 20, 21). The other 29 students only gave one reason each.

Table 11: Purpose of receiving feedback

\begin{tabular}{|l|c|}
\hline \multicolumn{1}{|c|}{ Purpose } & No. of Respondent \\
\hline Correcting mistakes & 16 \\
\hline Improving writing via mistakes & 11 \\
\hline Improving English knowledge & 7 \\
\hline Improving grammar & 4 \\
\hline Teacher's concern about student's weaknesses & 1 \\
\hline Getting good results & 1 \\
\hline
\end{tabular}

With reference to Table 12, upon receiving comments and corrections from their academics, 30.3 percent (10/33) said that they would read all the comments very carefully and would reflect on all the comments (feedback) very carefully. None of the student commented that he/she did not look at or think about the feedback carefully. This shows that the respondents acknowledged the importance of the feedback given by their academics.

Table 12: How much of each writing work do you read over again when your lecturer returns it to you?

\begin{tabular}{|l|c|c|}
\hline $\begin{array}{c}\text { How much of each writing work do you } \\
\text { read over again when your lecturer } \\
\text { returns it to you? }\end{array}$ & $\begin{array}{c}\text { First / Second } \\
\text { Draft }\end{array}$ & Final Draft \\
\hline None of it & nil & Nil \\
\hline Some of it & $9(27.3 \%)$ & $8(24.2 \%)$ \\
\hline Most of it & $14(42.4 \%)$ & $8(24.2 \%)$ \\
\hline All of it & $10(30.3 \%)$ & $17(51.6 \%)$ \\
\hline
\end{tabular}

Table 13 indicates that the group of student respondents had full confidence in their academics. This was because 75.8 percent $(25 / 33)$ of the students reported that they would either think about all or most of the feedback received in their first and second draft and $69.7 \%(23 / 33)$ would think carefully of the comments and corrections in the final draft. None responded negatively to the item.

Table 13: How many of your lecturer comments and corrections do you think about carefully?

\begin{tabular}{|l|c|c|}
\hline $\begin{array}{c}\text { How many of your lecturer comments } \\
\text { and corrections do you think about } \\
\text { carefully? }\end{array}$ & $\begin{array}{c}\text { First / Second } \\
\text { Draft }\end{array}$ & Final Draft \\
\hline None of it & nil & Nil \\
\hline
\end{tabular}




\begin{tabular}{|l|c|c|}
\hline Some of it & $8(24.2 \%)$ & $10(30.3 \%)$ \\
\hline Most of it & $14(42.5 \%)$ & $10(30.3 \%)$ \\
\hline All of it & $11(33.3 \%)$ & $13(39.4 \%)$ \\
\hline
\end{tabular}

\section{Academic's Interview}

In order to find answers to research question 2: 'What are the common practices and styles of giving feedback by the lecturers in a Malaysian public university', another group of respondents was required. Six academics teaching the writing module were interviewed. This was conducted in order to confirm, agree or disagree and to add to the answers and views given by the students via the questionniare form.

All the academics who were interviewed, viewed feedback as a way to make students know and aware of their mistakes. Four of the academics stated that written feedback alone is insufficient for many of their students, due to the following reasons:

1) Being weak in English makes some students unable to correct their own mistakes, especially if the lecturer uses the technique of circling and labelling error type.

2) The project paper is unlike other genres that they have learned in their secondary education.

3) The students have low to intermediate proficiency level and are not able to correct the feedback given on organisation and ideas/content.

In view of the three main reasons, the academics had to resort to face-to-face/verbal feedback. They had to further provide examples and guidelines on grammar, word choice, organization, and ideas/content. Two of the academics being interviewed said that they would need to speak in Malay or in the students' mother tongue, in order to make the students understand the mistakes, especially in organisation and ideas/content. All six academics said they allowed an average of three drafts. This was because the more the students wrote, the more likely they would learn and become good writers.

\section{DISCUSSION}

Based on the results from the present study, there are a few points that can be highlighted. The first is on the importance of giving feedback on content and ideas. Academic writing primarily stresses on content and ideas. According to an article entitled "Features of Academic Writing" (n.d.), "Academic writing in English is linear, which means it has one central point or theme with every part contributing to the main line of argument, without digressions or repetitions. Its objective is to inform rather than entertain' (p. 1). Irvin (2010) also supports the description of an academic written work.

Based on this point, content and ideas are important. This is supported by Mirzaii and Aliabadi (2013) when they found that '...there was a shift in focus from mere attention to the structural aspects of writing-grammar rules and vocabulary item... to one attending to both structure and content' (p. 192).

As mentioned by Byrne (1979), writing mechanics such as orthography and punctuation are used to present the meaning of the piece of writing. Writing has a communicative value and thus writers should be made aware of the significant role of 
writing mechanics in conveying a meaning. Instead of giving the learners rigid rules, it would be better to encourage them to consider the effect on the reader if, for example, sentence or paragraph boundaries are not marked.

Besides writing mechanics, another important issue that is discovered from this research is how errors are highlighted. With regard to "label error type", Al-Maari (2010) said:

Teachers should train their students to correct their own errors and should give them the chance to do so. Actually, there are so many ways to help students correct themselves. While writing for instance, teachers can use some correcting codes to indicate to students that there is an error instead of directly giving them the correction ...(p. 4).

There are many research studies that indicate indirect feedback options have a greater effect than direct feedback on accuracy performance (Jamalinesari, Rahimi, Gowhary, \& Azizifar, 2015; Ahmadi-Azad, 2014; Erel \& Bulut, 2007; Ferris, 2006; Lalande, 1982). However, this is not true with this group of Malaysian students. The study finds that direct oral feedback in combination with direct written feedback had a greater effect than direct written feedback alone on improved accuracy over time, and merely highlighting errors did not work with the students.

This question on 'How much do you enjoy writing in English' is also important because many agree that perceptions and motivations toward an activity is crucial. According to Bond (2002), in her article entitled Profile of a Successful Language Learner, she says that her research subject, Sarah, being 'a well-motivated and self-initiating learner, taking responsibility for her learning, and creating her own learning opportunities' has helped Sarah to learn another language. Thus, indirectly it is very important for a learner to enjoy the task for him or her to succeed. "Enjoy" can be related to Sarah being "well-motivated".

Another significant finding from this study is that there was a decline in enjoying writing very much from 42.2 percent (14/33 students) to 30.3 percent $(10 / 33$ students). Why is this so? One of the possible reasons is that many people do not like to be corrected. Based on Bond's (2002) respondent, "Sarah admits to feelings of frustration when she reaches a plateau in language learning. She also becomes demotivated when she realises that her Portuguese will never reach the level of her English... She dislikes people correcting her..." (p. 2).

In a research by Flower et al., (1990), they discovered a problem that the students faced during the transition period of entering the academic discourse community at tertiary level. Flower et al. (1990) said the students have to know the correct academic conversation that project knowing the textual methods, expectations, and formulaic expressions specifically for the discourse. Being low to intermediate students, the transition process towards what is required at tertiary level writing was a struggle to most students. One solution to this problem was the use of both oral and written feedback to ensure understand and to boost confidence in writing.

From the academics' interview, the finding from the present study is supported by Bitchener, Young, and Cameron (2005) who conducted a research and revealed that with the combination of oral feedback and direct written feedback, the effect was much greater than only having written feedback as the combination of both feedback enhanced accuracy and also improved the used of grammar items such as tenses and articles. 


\section{CONCLUSION}

In order to contribute to the need for further research related to issues on the value of providing corrective feedback to L2 writers, the present study investigated the extent to which different types of feedback helped L2 writers improve the accuracy of their use in new pieces of writing. It is found that the combination of full, explicit written and oral feedback enabled them to write with significantly greater accuracy in their writing than was the case.

From this study, it can be suggested that Malaysian second language classroom writing academics should provide their students with oral feedback as well as written feedback. In addition, local errors (grammar, vocabulary and mechanics) should be focused in classrooms on a regular basis so that students benefit from the learning process. This research also would like to propose that academics to discuss with their students which linguistic errors should be focused on.

\section{REFERENCES}

Abdullah, H., \& Sidek, H.M. (2012). L2 Writing feedback: Alignment of instructional planning and implementation. ELTED, 15, 15-24.

Ahmadi-Azad, S. (2014). The effect of coded and uncoded written corrective feedback types on Iranian EFL learners' writing accuracy. Theory and Practice in Language Studies, 4, 1001-1008.

Al-Maari, R. (2010). Is there a right way to deal with errors in second and foreign language learning? Retrieved from http://www.articlesbase.com/languagesarticles/is-there-a-right-way-to-deal-with-errors-in-second-and-foreign-languagelearning-1869866.html

Bitchener,J., Young S., \& Cameron, J. (2005). The effect of different types of corrective feedback on ESL student writing. Journal of Second Language Writing, 14, 191-205.

Bond, K. (2002, December). Profile of a successful language learner. Retrieved from http://www3.telus.net/linguisticsissues/successful.html

Byrne, D. (1979). Teaching writing skills. In Teaching English to speakers of other languages TESOL Writing. Retrieved from http://www.teachingstylesonline.com/writing tesol situation.html

Che Musa, H., Koo Y. L., \& Azman, H. (2013). Exploring English language learning and teaching in Malaysia. GEMA Online ${ }^{\mathrm{TM}}$ Journal of Language Studies, 12(1), 35-51.

Creswell, J. W. (2012). Educational Research. Planning, conducting and evaluating quantitative and qualitative research. Boston, USA: Pearson Education.

Erel, S., \& Bulut, D. (2007). Error treatment in L2 writing: A comparative study of direct and indirect coded feedback in Turkish EFL context. Journal of Institute of Social Sciences, 23, 397-415.

Fareed, M., Ashraf, A., \& Bilal, M. (2016). ESL learners' writing skills: Problems, factors and suggestions. Journal of Education and Social Sciences, 4 (2):1, 81-92.

Features of academic writing (n.d.). Retrieved from http://www.uefap.com/writing/feature/featfram.htm

Ferris, D. R. (2002). Treatment of error in second language student writing. Ann Abor: University of Michigan Press.

Ferris, D. R. (2006). Does error feedback help student writers? New evidence on the shortand long-term effects of written error correction. In K. Hyland \& F. Hyland (Eds.), Feedback in second language writing: Contexts and issues (pp 81-104). Cambridge, UK: Cambridge University Press. 
Flower, L., Stein, V., Ackerman, J., Kantz, M., McCormick, K., \& Peck, W. (1990). Reading-to-write: Exploring a cognitive and social process. New York: Oxford University Press.

Hattie, J. \& Timperley, H. (2007) The power of feedback. Review of Educational Research, March 2007, 77 (1), 81-112.

Irvin, L.L. (2010). What is 'academic' writing? In Lowe, C. \& Zemiliansky, P. (eds). Writing Spaces: Readings on Writing, Volume 1. US: Parlor Press.

Jalaluddin, N. H., Norsimah, M. A., \& Kesumawati, A. B. (2008). The mastery of English Language among lower secondary school students in Malaysia: A linguistic analysis. European Journal of Social Sciences, 7/2.

Jamalinesari, A., Rahimi, F., Gowhary, H. \& Azizifar, A. (2015). The effects of teacherwritten direct vs indirect feedback on students' writing. Procedia - Social and Behavioural Sciences 192, 116 - 123.

Lalande, J. (1982). Reducing composition errors: An experiment. Modern Language Journal, 66.2, 140-149

Lee, I. (2003). L2 writing teachers' perspectives, practices and problems regarding error feedback. Assessing Writing, 8, 216-237.

Mirzaii, M., \& Aliabadi, R. B. (2013). Direct and indirect written corrective feedback in the context of genre-based instruction on job application letter writing. Journal of Writing Research, 5(2), 191-213.

Montgomery, J. L., \& Baker, W. (2007). Teacher-written feedback: Student perceptions, teacher self-assessment, and actual teacher performance. Journal of Second Language Writing, 16, 82-99.

Malaysian University English Test (MUET). (2004). Malaysian Examination Council.

Myles, J. (2002). Second language writing and research: The writing process and error analysis in student texts. TESL - EJ, 6(2).

Naginder Kaur. (2006). Non-autonomy and low-English proficiency among Malaysian students: Insights from multiple perspectives. In Kamisah Ariffin, Mohd. Rozaidi Ismail, Ngo Kea Leng, \& Roslina Abdul Aziz. (Eds.). English in the Malaysian context (pp. 21-34). Shah Alam: University Publication Centre (UPENA) UiTM.

Nunan, D. (1989). Designing tasks for the communicative classroom. Cambridge University Press, United Kingdom.

Peterson, S. S., \& McClay, J. (2010). Assessing and providing feedback for student writing in Canadian classrooms. Assessing Writing, 15(2), 86-99.

Rogers, J. (2001). Adult learning. Buckingham: Open University Press. 